\title{
A case of polymelia associated with syndactyly in Didelphis aurita (Wied-Neuwied, 1826)
}

\author{
H. B. Araujo * (D), D. Costa-Pinto (D), C. S. C. de Castro $^{a, b}$ (D) and J. R. Pires ${ }^{a}$ \\ ${ }^{a}$ Clínica de Recuperação de Animais Silvestres - CRAS, Universidade Estácio de Sá - UNESA, Estrada Boca do Mato, \\ 850, Vargem Pequena, CEP 22783-320, Rio de Janeiro, RJ, Brasil \\ befúgio Ecológico Fazenda Gato do Mato - REGAMA, Estrada MM-77, Km 8,5, Santa Maria Madalena, RJ, Brasil \\ *e-mail: helenaba15@yahoo.com.br
}

Received: November 19, 2018 - Accepted: April 1, 2019 - Distributed: August 31, 2020

(With 7 figures)

\begin{abstract}
In January 2018, a young male of Didelphis aurita (Wied-Neuwied, 1826), the Brazilian common opossum, was admitted for veterinary evaluation at the Recovery Clinic of Wild Animals of Estácio de Sá University, CRAS, in Rio de Janeiro, Brazil, due to the presence of a partially duplicated right hind limb. After x-ray evaluation, polymelia associated with syndactyly was diagnosed. The images revealed the following alterations on the right limb: single femur with increased diameter, two tibiae, two fibulae and absence of hallux. The observed malformations were restricted to the hind right limb, which remains functional. This is the first report of such anomalies in an individual of Didelphis aurita.
\end{abstract}

Keywords: polymelia, syndactyly, Didelphis aurita, bone malformation.

\section{Relato de caso de polimelia associada a sindactilia em Didelphis aurita (Wied-Neuwied, 1826)}

\section{Resumo}

Em janeiro de 2018, um macho jovem de Didelphis aurita (Wied-Neuwied, 1826), o gambá-de-orelha-preta, foi recebido para atendimento veterinário na Clínica de Recuperação de Animais Silvestres (CRAS) da Universidade Estácio de Sá, no Rio de Janeiro, por ser portador de membro posterior direito parcialmente duplicado. Após exame radiográfico, constatou-se a ocorrência de polimelia associada a sindactilia. As imagens radiográficas revelaram as seguintes alterações no membro posterior direito: um fêmur com diâmetro aumentado, duas tíbias, duas fíbulas e ausência de hálux. As malformações observadas restringiram-se apenas ao membro posterior direito, o qual mantém sua funcionalidade. Essas alterações nunca antes foram descritas na espécie Didelphis aurita.

Palavras-chave: polimelia, sindactilia, Didelphis aurita, malformação óssea.

\section{Introduction}

Rio de Janeiro is a city particularly famous for its natural beauties. Considering the environment of its metropolitan region, many officially protected areas are continuously threatened by the expanding surrounding limits of densely populated urban areas. This condition predisposes the frequent contact of many wildlife species with the local population (Ditchkoff et al., 2006). Some of these encounters are harmful for the local fauna because many people do not know how to deal with such animals. For this reason, the local veterinary practice should be aware of the most common diseases afflicting wildlife, as well as any emerging pathology. The knowledge of such conditions can be essential to mitigate its effects, aiming at the welfare of both wildlife individuals and local human population. Finally, the understanding of the etiology of these pathologies can help planning reintroduction of rehabilitated individuals in the wild, contributing to the preservation of local biodiversity (Gonçalves et al., 2016).

The Brazilian common opossum, Didelphis aurita (Wied-Neuwied, 1826), is part of the wildlife biodiversity of Brazil. It occurs in the Araucaria and Atlantic Forests, the latter forest being the predominant original vegetation in the State of Rio de Janeiro. This species is listed as Least Concern by the IUCN classification (Astua de Moraes et al., 2015), the main reasons being mainly due to its wide distribution, presumed large population, tolerance to habitat modification, occurrence in several protected areas and because it is unlikely to be declining at nearly the rate required to qualify for listing in a threatened category (Astua de Moraes et al., 2015). This species is known to be locally hunted or trapped for food, sport and as predators of poultry. However, it does not appear to have 
been adversely affected by human settlement. Moreover, commercial hunting for the fur trade does not appear to have much impact in Didelphis aurita population (Astua de Moraes et al., 2015). Considering the wildlife in Rio de Janeiro, this species is one of the most frequently encountered by the local inhabitants (Bonvicino et al., 2002).

The aim or the present work is to report a case of polymelia associated with syndactyly in an individual of Didelphis aurita found in the State of Rio de Janeiro, Brazil. These pathologies are congenital defects (Retnam et al., 2016). To the knowledge of the authors, this is the first report of such anomalies in that species.

\section{Case History}

In January 2018, a young male of Didelphis aurita was admitted at the Rehabilitation Centre of University Estácio de Sá, CRAS, for veterinary evaluation due to the presence of a partially duplicated right hind limb (Figures 1 and 2). Case history included the death of the female parent and the release of the other youngsters, as they appeared to be normal. Regarding opossums, the existence of an extra limb

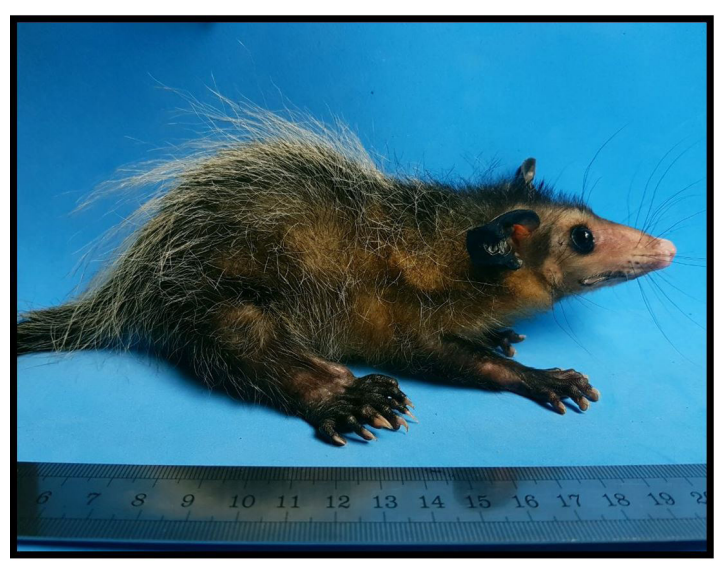

Figure 1. A young male of Didelphis aurita from Rio de Janeiro, Brazil, affected by polymelia and syndactyly at the right hind limb. Note that limb duplication is partial.

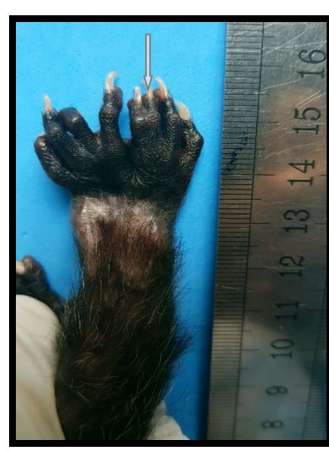

A

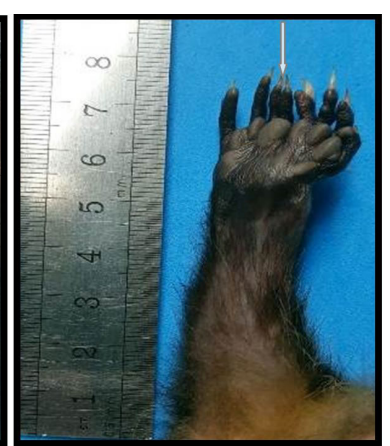

B
Figure 2. Detail of the affected right hind limb of Didelphis aurita. (A) dorsal view; (B) plantar view. Digits affected by syndactyly are indicated by arrows. could supposedly impair the animal's normal activities for survival. At the time of admission, this individual weighed $62 \mathrm{~g}$ and was $27 \mathrm{~cm}$ long.

The occurrence of one or more supernumerary limbs in one individual is a congenital defect designated as polymelia. It is quite common in animals although rarely reported in humans (Retnam et al., 2016). The extra limb may appear in different positions of the body and can be deformed or shrunken (Retnam et al., 2016). There are cases in which the limb is partially duplicated. According to the region of the body to which the extra limb is attached, a specific term is used to designate the location. In this way, polymelia is called cephalomelia if the limb is attached to the head, notomelia if attached to the backbone, thoracomelia if attached to the thorax and pygomelia if attached to the pelvis (Retnam et al., 2016).

Polymelia has been reported in amphibians (Hassine et al., 2011), cattle (Muirhead et al., 2014; Kim et al., 2001; Barua et al., 2014), birds (Rogers et al., 2016; Abu-Seida, 2014), and domestic dogs (Daneze and Brasil, 2018), as well as in humans (Retnam et al., 2016). However, to the knowledge of the authors, it has never been reported in opossums.

The individual of Didelphis aurita affected by polymelia and syndactyly from this report was found in São Gonçalo, a county of the metropolitan region of the State of Rio de Janeiro. This area is particularly densely populated and human occupation is ever expanding (Santos and Pinto, 2006).

In São Gonçalo County, there is an official conservation unit called Área de Proteção Ambiental do Engenho Pequeno (APAEP), where opossums are found (Santos and Pinto, 2006). For this reason, though not informed, this animal with polymelia and syndactyly might have come from this conservation unit.

After a thorough physical examination of the accessory limb, however, two digits were notably fused, characterizing also a case of syndactyly associated with polymelia. Apart from the limb malformations, no other pathological condition was observed in the individual after clinical examination. The extra limb demonstrated to be quite functional (Figure 3). Complete blood counts were normal. The animal demonstrated normal appetite and activity.

\section{Results}

The patient was submitted to radiographic examination for bone development assessment and the occurrence of other malformations apart from the right hind limb duplication.

Results show (see Figures 4, 5 and 6) that bone malformation is apparently restricted to the right limb. The skull and other parts of the body seem to be normal. The following alterations were revealed in the $\mathrm{x}$-ray evaluation of the right limb: single femur with increased diameter, two tibiae and two fibulae, two metatarsal bones of the caudal right toe are fused and complete absence of hallux. The cranial duplicated part of the right limb 


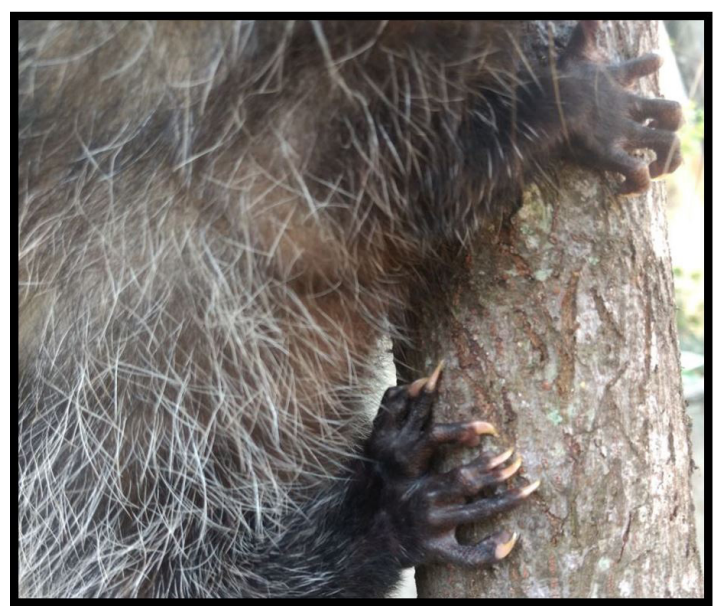

Figure 3. Both distal parts of the right limb appear to be functional. Note the digits are active during climbing.

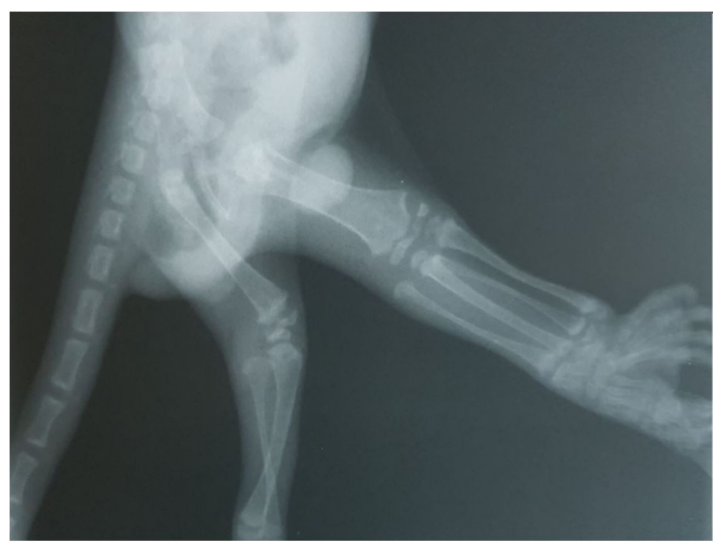

Figure 4. X-ray imaging showing the proximal portions of the hind limbs. The patient was positioned on right lateral decubitus. Note the existence of two right tibiae and two right fibulae. The right femur is thicker than the contralateral one.

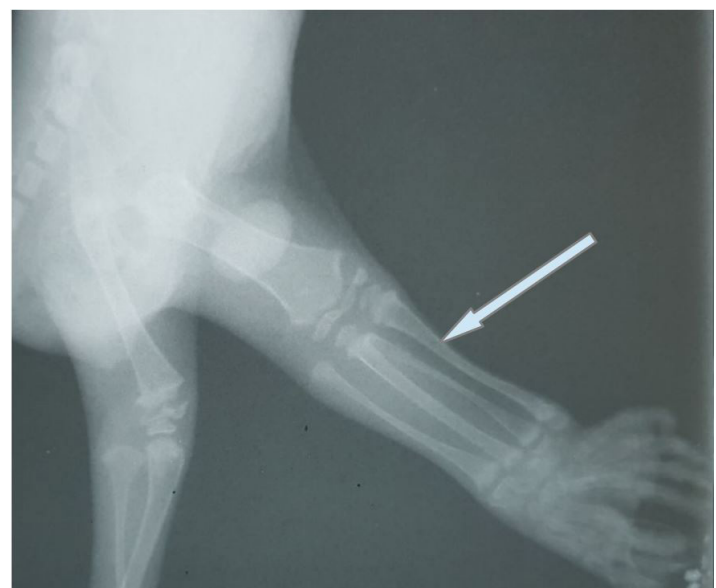

Figure 5. X-ray imaging showing detail of the right limb (arrow). Note the most cranial duplicated part of the limb forms a joint with the femur, whereas the caudal part does not seem to be articulated.

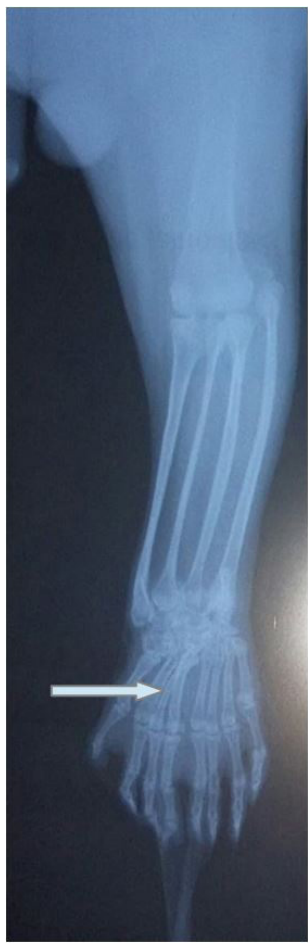

Figure 6. X-ray imaging of the right hind limb, dorsal-plantar positioning. The partial duplication of the right limb can be observed: there is one femur, two tibiae and two fibulae. Two metatarsal bones are fused (arrow), confirming the presence of syndactyly. Note the missing hallux.

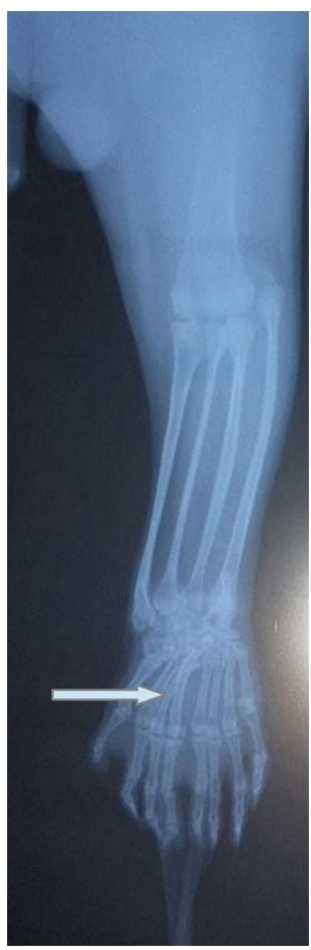

Figure 7. X-ray imaging showing the right limb (arrow) after three months of patient admission. No significant change was observed regarding bone and joint development. 
articulates with the single femur. The caudal tibia and fibula, although functional, seem not to be part of the joint to the femur.

After three months, the animal has grown considerably. Its length has increased to $60 \mathrm{~cm}$, including the tail, and its weight is presently $879 \mathrm{~g}$. Another x-ray examination of the extra limb evaluated any change in bone development (Figure 7). No significant changes appeared when compared to the first images.

\section{Discussion}

Opossums have a relatively short lifespan. When living in the wild, their average survival time is 2 years, whereas in captivity this lifespan increases to 4 years (Gentile et al., 2000). For this reason, opossums offer an opportunity to study physiological alterations due to aging.

In the present case, in the near future, the double femur-tibial articulation will predispose the occurrence of osteoarthritis due to constant trauma. If osteoarthritis is present, pain will impair movement, condition with poor prognosis. Since the animal is clinically healthy up to now, sequential radiographic evaluations will enable detection of any alterations in bone or joint.

Opossums are very prolific, yielding average litters of above five individuals. Their gestation period is quite short, of approximately 15 days. In this way, they are frequently breeding which is also an explanation for their keeping a constant population in urban areas (Gentile et al., 2000). On the other hand, wildlife is vulnerable to many teratogenic substances produced by human activities. The occurrence of congenital defects, such as polymelia, may have a genetic or an environmental cause (Ditchkoff et al., 2006; Hussein et al., 2012). Gene disorders investigated through chromosome analysis will determine if the anomaly in the present case has a genetic origin. Chemical products from the environment can produce congenital anomalies (Hussein et al., 2012). This condition will certainly affect not only the local population, but also the coexisting wildlife in such places.

Surgical removal of the extra limb aims at improving the well-being of the patient and its cosmetic appearance. There are cases where the position of the accessory limb may result in constant injury by the animal's normal activities, being the indication of limb excision. However, surgery of animals with non-disturbing supernumerary digits is optional (Hussein et al., 2012). Since the individual of case hereby reported has not shown any sign of discomfort yet, the removal of the supernumerary limb is not considered. In this respect, the follow-up of bone development by sequenced diagnostic imaging is important in case this condition changes.

\section{Concluding Remarks}

This case is the first report of polymelia associated with syndactyly in Didelphis aurita. It may help understand how such pathologies progress and assess prognosis for patients carrying these anomalies.
Due to the short lifespan of the species, the study of polymelia and syndactyly in Didelphis aurita can bring insight to bone development and ageing in mammals.

\section{Acknowledgements}

The authors would like to thank University Estácio de Sá for supporting this study by providing for the x-ray exams.

\section{References}

ABU-SEIDA, A.M., 2014. Amputation of polymelia in a layer chicken. Avian Diseases, vol. 58, no. 2, pp. 330-332. http://dx.doi. org/10.1637/10682-100413-Case.1. PMid:25055644.

ASTUA DE MORAES, D., DE LA SANCHA, N. and COSTA, L., 2015 [viewed 29 July 2018]. Didelphis aurita [online]. Cambridge: The IUCN Red List of Threatened Species. e.T40500A22175929. http://dx.doi.org/10.2305/IUCN.UK.2015-4. RLTS.T40500A22175929.en.

BARUA, P.M., KALITA, D., SARMA, D.K., KALITA, M., DAS, P. and LAHKAR, D., 2014. Polymelia in a crossbred Jersey cow (Bos Taurus): A case report. DHR International Journal of Medical Sciences, vol. 5, no. 3, pp. 96-98.

BONVICINO, C.R., LINDBERGH, S.M. and MAROJA, L.S., 2002. Small non-flying mammals from conserved and altered áreas oc atlantic forest and cerrado: comments on their potencial use for monitoring environment. Brazilian Journal of Biology $=$ Revista Brasileira de Biologia, vol. 62, no. 4b, pp. 1678-4375. http://dx.doi.org/10.1590/S1519-69842002000500005.

DANEZE, E.D. and BRASIL, F.B.J., 2018. Polymelia and duplication of the descending colon in a Poodle dog - a case report. Veterinarski Arhiv, vol. 88, no. 1, pp. 149-157. http:// dx.doi.org/10.24099/vet.arhiv.160922.

DITCHKOFF, S.S., SAALFELD, S.T. and GIBSON, C.J., 2006. Animal behavior in urban ecosystems: modifications due to human-induced stress. Urban Ecosystems, vol. 9, no. 1, pp. 5-12. http://dx.doi.org/10.1007/s11252-006-3262-3.

GENTILE, R., D'ANDREA, P.S., CERQUEIRA, R. and SANTORO MAROJA, L., 2000. Population dynamics and reproduction of marsupials and rodents in a Brazilian rural area: a five year study. Studies on Neotropical Fauna and Environment, vol. 35, no. 1, pp. 1-9. http://dx.doi.org/10.1076/0165-0521(200004)35:1;1-M;FT001.

GONÇALVES, J.A., ALMEIDA, V.L., RIBEIRO, D.G.A., SOBRINHO, R.F.G., MILLIOLE, R.R., PIRES, J.R. and SOARES, M.A. 2016 [viewed 29 July 2018]. Mamíferos silvestres resgatados na Zona Oeste do Rio de Janeiro - RJ. Novo Enfoque: Caderno de Saúde e Meio Ambiente [online], no. 21, pp. 20-27. Available from: http://www.castelobranco.br/revista/index.php/ Janeiro16/article/viewFile/15/5

HASSINE, J.B., DE BUFFRÉNIL, V. and NOUIRA, S., 2011. First record of morphological abnormalities in natural populations of two amphibian species in Tunisia. Journal of Herpetology, vol. 45, no. 4, pp. 465-471. http://dx.doi.org/10.1670/10-002.1.

HUSSEIN, K.E., ALI, M.M. and GALAL, A.F., 2012. Successful surgical treatment of a supernumerary ectopic limb in a cattle calf. European Journal of Veterinary Medicine, vol. 1, no. 1, pp. 28-35.

KIM, C., YEO, S., CHO, G., LEE, J., CHOI, M., WON, C., KIM, J. and LEE, S., 2001. Polymelia with two extra forelimbs at the right scapular region in a male Korean native calf. The Journal of Veterinary Medical Science, vol. 63, no. 10, pp. 11611164. http://dx.doi.org/10.1292/jvms.63.1161. PMid:11714039. 
MUIRHEAD, T.L., PACK, L.A. and RADTKE, C.L., 2014. Unilateral notomelia in a newborn Holstein calf. The Canadian Veterinary Journal. La Revue Veterinaire Canadienne, vol. 55, no. 7, pp. 659-662. PMid:24982517.

RETNAM, K.R., DHANALAKSHMI, V., FLORA JUANITA, E. and GNANAMUTHU, J., 2016. Polymelia associated with lipomyelomeningocele: a case report. International Journal of Anatomical Research, vol. 4, no. 3, pp. 2813-2816.
ROGERS, K.H., METE, A., MCMILLIN, S. and SHINN, R., 2016. Polymelia and syndactyly in a Swainson's hawk (Buteo swainsoni). Journal of Wildlife Diseases, vol. 52, no. 1, pp. 114117. http://dx.doi.org/10.7589/2014-05-121. PMid:26555107.

SANTOS, M.G. and PINTO, L.J.S., 2006. Riqueza biológica da Área de Proteção Ambiental do Engenho Pequeno, São Gonçalo, Estado do Rio de Janeiro. Interagir: Pensando a Extensão, vol. 9, pp. 39-44. 